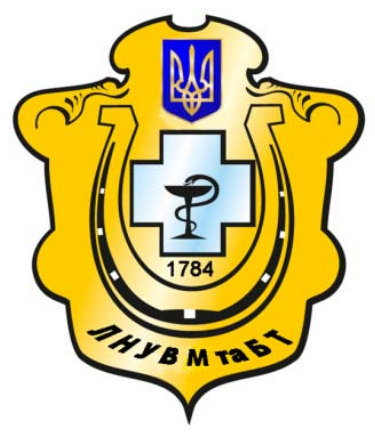

Науковий вісник Львівського національного університету ветеринарної медицини та біотехнологій імені С.3. Гжицького

Scientific Messenger of Lviv National University of Veterinary Medicine and Biotechnologies named after S.Z. Gzhytskyj

doi:10.15421/nvlvet7729

ISSN 2518-7554 print

ISSN 2518-1327 online

$\underline{\text { http://nvlvet.com.ua/ }}$

УДК 619: 615: 619-091

\title{
Діазинон. Основні аспекти біологічної дії, токсикологічні властивості та патоморфологія отруснь
}

\author{
В.В. Туманов \\ borisfennt1980@gmail.com
}

Львівський національний університет ветеринарної медицини та біотехнологій імені С.3. Гжицького, вул. Пекарська, 50, м. Львів, 79010, Україна

\begin{abstract}
У статті наведено дані щодо хімічних властивостей та основних аспектів біологічної дї діазинону - фосфорорганічного пестициду, що широко використовується як препарат з вираженими акарицидними та інсектицидними властивостями. Проаналізовано літературні дані щзодо метаболізму, розподілу в різних органах та системах, а також шляхів виведення діазинону та продуктів його обміну з організму. Наведено показники напівлетальних доз (LD $\left.D_{50}\right)$ діазинону. Висвітлено особливості патогенезу та детально описано клінічні ознаки гострого отруєння фосфорорганічними сполуками. Експериментальні дані свідчать про те, щьо дія на організм фосфорорганічних пестицидів включає: мускариноподібні ефекти, нікотиноподібну дію, а також центральні ефекти, щчо виникають унаслідок впливу на центральну нервову систему і супроводжуються порушенням ї̈ функиії. Проаналізовано патологоанатомічну картину отруєння фосфорорганічними пестицидами. Описано вплив діазинону на органи імунної системи, а також здатність індукувати ендокринні розлади. Також наведено літературні дані щодо потениійної мутагенної та канцерогенної дї діазинону. Окреслено коло маловивчених питань щодо особливостей виникнення структурних змін та розвитку клінічних ознак за впливу різних доз діазинону, а також окремих аспектів судово-ветеринарної діагностики отруєнь ссавиів та птахів фосфорорганічними пестицидами

Ключові слова: діазинон, фосфорорганічні пестицици, отруєння, патоморфологія, ацетилхолінестераза, канцерогенна та мутагенна дія, діазоксон, некротичні та дистрофічні зміни нервових клітин, демієлінізація.
\end{abstract}

\section{Диазинон. Основные аспекты биологического действия, токсикологические свойства и патоморфология отравлений}

\author{
В.В. Туманов \\ borisfennt1980@gmail.com
}

\begin{abstract}
Львовский национальный университет ветеринарной медицины и биотехнологий имени С.3. Гжсицкого, ул. Пекарская, 50, г. Львов, 79010, Украина
\end{abstract}

\begin{abstract}
В статье приведены данные химических свойств и основных аспектов биологического действия диазинона - фосфорорганического пестицида, широко используемого в качестве препарата с выраженными акарицидными и инсектицидными свойствами. Сделан анализ литературных данных по метаболизму, распределению в различных органах и системах, а также относительно путей вывода диазинона и продуктов его обмена из организма. Приведены показатели полулетальных доз $\left(L D_{50}\right)$ диазинона. Освещены особенности патогенеза и подробно описаны клинические признаки острого отравления фосфорорганическими пестицидами. Изложенные данные свидетельствуют о том, что воздействие на организм фосфорорганических пестицидов включает: мускариноподобные эффекты, никотиноподобное действие, а также иентральные эффекты, возникающие вследствие воздействия на иентральную нервную систему и сопровождающиеся нарушением ее функиии. Проведен анализ патологоанатомической картины отравления фосфорорганическими пестицидами. Описано влияние диазинона на органы иммунной системы, а также способность индуцировать эндокринные расстройства. Также приведены литературные данные о потенциальном мутагенном и каниерогенном действии диазинона. Очерчен круг
\end{abstract}

\section{Citation:}

Tumanov. V. (2017). Diazinon. The main aspects of biological effect, toxicological properties and pathomorphology poisoning. Scientific Messenger LNUVMBT named after S.Z. Gzhytskyj, 19(77), 131-136. 
малоизученных вопросов об особенностях возникновения структурных изменений и развития клинических признаков при воздействии различных доз диазинона, а также отдельных аспектов судебно-ветеринарной диагностики отравлений млекопитающих и птиц фосфорорганическими пестицидами.

Ключевые слова: диазинон, фосфорорганические пестициды, отравления, патоморфология, ацетилхолинэстераза, канцерогенное и мутагенное действие, диазоксон, некротические и дистрофические изменения нервньх клеток, демиелинизаичия.

\title{
Diazinon. The main aspects of biological effect, toxicological properties and pathomorphology poisoning
}

\author{
V. Tumanov \\ borisfennt1980@gmail.com

\begin{abstract}
Lviv National University of Veterinary Medicine and Biotechnologies named after S.Z. Gzhytskyi, Pekarska Str., 50, Lviv, 79010, Ukraine
\end{abstract}

The article represents data on chemical properties and main aspects of the biological action of the diazinon - organophosphate pesticide that is widely used as a drug with marked acaricidal and insecticidal properties. Analyzed published data on metabolism, diazinon accumulation in various organs and systems, and ways of removing from the body. The article shows the median lethal dose $\left(L D_{50}\right)$ diazinon for various kinds of animals. The special features of the pathogenesis of poisoning, the main mechanism of action of toxic organophosphorus pesticides is the phosphorylation and inhibition of acetylcholinesterase, resulting in a marked accumulation of acetylcholine in the cholinergic synapses, excessive stimulation of nerves and muscles, disruption passage of nerve impulses.

The article detailed the clinical signs of acute poisoning by organophosphate compounds. These data indicate that the effects on the body organophosphorus pesticides includes muscarinic effects (sialorrhea and excessive secretion of sweat glands, bronchorrhea, increased motility of the gastrointestinal tract, accompanied by spastic contractions of the intestinal wall, vomiting and gastroenteritis), nicotine action (miofibrillation, rigidity pectoral muscles, paralysis of respiratory muscles with the development of sudden hypoxemia) and central effects (arising from the impact of the central nervous system and are accompanied by violation of its function). The analysis pathmorphology of poisoning of the organophosphate pesticide. These data indicate that structural changes diazinon poisoning is less specific than clinical signs and characterized by: the development of the circulatory disorders (acute congestive hyperemia recorded and hemorrhage), the appearance of dystrophic and necrotic changes parenchymal elements of the brain and spinal cord, liver, kidneys and so on. Also recorded alterations changes ganglion cells and spinal cord autonomic ganglion, proliferation of glial cells, and for subacute and chronic poisoning - disintegration of the myelin and nerve fibers axial cylinder. Described diazinon influence on organs of the immune system and ability to induce endocrine disorders. There are published data on the potential mutagenic, carcinogenic and teratogenic effects of the diazinon. The range of problems researd structural changes by the origin and development of clinical evidence for the effect of different doses diazinon and certain aspects of forensic veterinary diagnostic poisoning mammals and birds of organophosphate pesticides.

Key words: diazinon, organophosphate pesticides, poisoning, pathomorphology, acetylcholinesterase, mutagenic and carcinogenic effects, diazokson, necrotic and dystrophic changes of nerve cells, disintegration of the myelin.

Фосфорорганічні пестициди, більшість 3 яких є токсичними сполуками, широко використовуються як інсектициди та акарициди, фунгіциди, гербіциди, родентициди, нематоциди, дефоліанти та десиканти, а також як терапевтичні засоби за лікування глаукоми, міастенії, атонії кишок, туберкульозу, злоякісних новоутворень тощо. У промисловості фосфорорганічні сполуки знайшли застосування як активні багатофункціональні присадки до мастил, використовуються під час флотації руд, виробництва розчинників, пластифікаторів, негорючих пластмас тощо. Вони поєднують у собі властивості мийних, протикорозійних і протизносних присадок іє антиокиснювачами і депресорами (WHO, 1998; Prodanchuk et al., 2005; Perelik pestytsydiv i ahrokhimikativ..., 2010; Nedopytanska, 2010; Kodonidi, 2011).

Одним 3 високоефективних неспецифічних фосфорорганічних інсектицидів $\epsilon$ діазинон (О,О-діетил O-2-ізопропіл-6-метилпіримідин-4-іл фосфоротіоат), що володіє вираженими акарицидними та нематоцидними властивостями, широко використовується у рослинництві та ветеринарній медицині. Відкрита речовина була Жизеном у 1950-1952 роках. Цьому відкриттю передувало фосфорилювання ензолізуючих ефірів (ацетооцтового ефіру) та кетонів (ацетилацетону) Шредером і Лоренцем у 1944 році. Жизен отримав гетероциклічні енольні сполуки конденсацією з ефіру $\beta$-кетокарбонової кислоти, потім вони були переведені в ефіри діметилкарбамінової кислоти. Надалі отримані еноли були фосфорильовані. Найбільш цікавим енольним з'єднанням став продукт конденсації ацетооцтового ефіру та ізобутірамідину (2-ізопропіл-4метил-6-оксіпірімідін). Його фосфорилювання О,Одіетилхлортіофосфатом призвело до утворення діючої речовини діазинону. Розробником та реалізатором діазинону на ринку стала швейцарська хімічна компанія Ciba-Geigy. Уперше діазинон був зареєстрований у США в 1956 році як діюча речовина препарату, призначеного для знищення мурах та гризунів (Debski et al., 2007; Nedopytanska, 2010; Kodonidi, 2011).

Діазинон у чистому вигляді - це безбарвна масляниста рідина, з температурою кипіння $89{ }^{\circ} \mathrm{C}$, зі слабким запахом. Молекулярна маса 304,4 . Погано розчиняється у воді (40 мг/л за температури $20{ }^{\circ} \mathrm{C}$ ), добре розчиняється у більшості органічних розчинників (ацетоні, бензолі, ксилолі, етанолі, хлороформі), швидко гідролізується в лужному та кислому середовищах. Водна емульсія змішується 3 більшістю 
гербіцидів та фунгіцидів. Точка кипіння $-89{ }^{\circ} \mathrm{C}$ за тиску 0,1 мм ртутного стовпа, тиск парів при $20^{\circ} \mathrm{C}-$

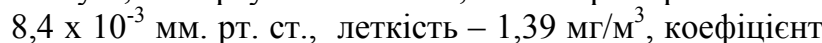

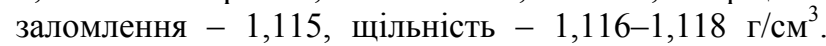
Діазинон швидко розкладається у грунті. Період напіврозпаду залежно від типу грунту та температури триває від кількох днів до кількох тижнів. На відміну від діазинону 2-ізопропіл-4-метил-6-гідроксипіримідин (ІМГП - основний метаболіт) високостійкий та високомобільний у грунті, а 2-1-гідрокси-1метил-етил-4-метил-6-гідроксипіримідин (мінорний метаболіт) також $є$ високомобільним. Деградація діазинону у воді відбувається шляхом гідролізу, швидше - у кислому середовищі, де період напіврозпаду становить до двох тижнів, тимчасом при нейтральних значеннях $\mathrm{pH}$ - до півроку. Діазинон у воді стійкий до фотолізу. Деградація у воді, як і в грунті, відбувається 3 утворенням діазоксону, що гідролізує до діетилтіофосфористої кислоти та 2ізопропіл-4-метил-6-гідроксипіримідину (Сох, 2000; Environmental Protection Agency, 2003; EFSA Scientific Report, 2006; Reregistration Eligibility Decision, 2006; Nedopytanska, 2010).

Діазинон при обробці грунту абсорбується коренями рослин та потрапляє в їхнє стебло та листя. В рослинах він швидко розпадається (період напіврозпаду коливається від 2 до 14 діб), але при низьких температурах, особливо в олійних культурах, його персистентність зростає. Деградація в рослинах відбувається переважно шляхом гідролізу. За технологічної обробки рослинної сировини (наприклад, яблук на соки та пасти) залишкові кількості діазинону суттєво зменшуються, проте за певних специфічних умов гідролізу можливе утворення продукту деградації десетил діазинону. Рівні вмісту десетил діазинону та його токсикологічна небезпека не з'ясовані і потребують вивчення. Незважаючи на швидку деградацію, залишки діазинону достатньо часто визначаються під час моніторингу сільськогосподарської продукції (Debski et al., 2007).

Діазинон належить до сполук контактної та кишкової дії. Фумігантна дія препарату досить слабка, що $\epsilon$ його перевагою з точки зору безпечності для людей та теплокровних тварин, які контактують 3 препаратом (Cherkesa, 1964; Aleksanrova and Goncharenko, 1983).

Дані щодо величин середньолетальних доз $\left(\mathrm{LD}_{50}\right)$ діазинону для різних тварин відрізняються. Зокрема за перорального введення діазинону лабораторним щурам $\mathrm{LD}_{50}$ становить 1160 мг/кг для самок та 1340 мг/кг - для самців, а для мишей коливається в межах 82-187 мг/кг. Згідно з даними (Diazinon. NPIC technical fact sheet) $\mathrm{LD}_{50}$ діазинону для щурів складає 300-850 мг/кг, мишей - 80-135 мг/кг, свиней 100 мг/кг, мурчаків (морських свинок) - 250355 мг/кг, кролів - 130 мг/кг, курей -8 мг/кг, качок 3,5 мг/кг, фазанів - 3,5 мг/кг.

За перорального потрапляння діазинон, як і інші фосфорорганічні пестициди швидко всмоктується. Розподіл в організмі та швидкість виведення залежать від виду тварини, в організм якої потрапив препарат. За внутрішньошлункового введення діазинону щурам у кількості 100 мг/кг концентрація діазинону та його метаболітів в організмі $\epsilon$ найвищою через 2 год. Розподіл у внутрішніх органах щурів такий (за зменшенням його концентрації): печінка - серце нирки - легені - селезінка - головний мозок. За нанесення діазинону на шкіру (900 мг/кг) лабораторним щурам концентрація діазинону спадає у такій послідовності: легені - серце - печінка - нирки - мозок селезінка. Рівень діазинону в мозку, легенях, нирках, серці, селезінці і печінці через 2 год після введення препарату в шлунок $є$ у 5-16 разів вищим, а в крові та сечі в 1,2-3 рази нижчим, ніж за аплікації на шкіру. Значну кількість діазинону (понад 20\% від виявленої кількості) виявляють у головному мозку після внутрішньошлункового введення, а також після аплікації на шкіру (Aleksanrova and Goncharenko, 1983).

У організмі діазинон метаболізує з утворенням діазоксону, детоксикація якого проходить під дією ферментів параоксонази, що міститься у печінці та крові шляхом гідролізу, десульфуризації та деоксигенації. Основна маса (більше ніж 60\%) діазинону та його токсичного метаболіту (діазоксону) виводиться з сечею досить швидко (від кількох годин до кількох діб) i майже не затримується в тканинах (Debski et al., 2007; Botha et al., 2015).

В основні токсичної дії діазинону та його метаболітів лежить пригнічення ацетилхолінестерази - ферменту, що руйнує ацетилхолін. Унаслідок цього ацетилхолін накопичується в холінергічних синапсах, розвивається надмірна стимуляція нервів та м'язів. У результаті порушення нормального проходження нервових імпульсів виникає тремор, що з часом переходить в параліч (Kagan, 1977; Kokshareva et al., 1990; Dagaev et al., 1991; Tomlin, 2006; Botha et al., 2015).

Незалежно від шляху потрапляння в організм діазинон, як і інші фосфорорганічні сполуки (у випадку надходження токсичних доз), спричиняють виражену клінічну картину отруєння. За механізмом виникнення симптоми гострого отруєння фосфорорганічними сполуками можна розділити на три групи: 1) мускариноподібні - пов'язані із збудженням М-холінорецепторів; 2) нікотиноподібні - зумовлені збудженням Н-холінорецепторів; 3) центральні - виникають унаслідок впливу фосфорорганічних сполук на центральну нервову систему і супроводжуються порушенням іiі функції. Патогенний вплив фосфорорганічних сполук охоплює різні органи і системи, оскільки відзначається холінергічна дія в усіх нервових структурах, у яких передача імпульсів здійснюється завдяки ацетилхоліну (центральна нервова система, залози зовнішньої секреції, гладкі м'язові елементи бронхів, кишечнику, судин, серце, гангліонарні та нервово-м'язові синапси, мозкова речовина наднирників тощо). Вислід отруєння, частота та вираженість клінічних симптомів залежать від дози та шляху надходження токсичних речовин (Cherkesa, 1964; Kagan, 1977; Dagaev et al., 1991; Hatjian et al., 2000).

Слід зазначити, що за отруєння фосфорорганічними інсектицидами спочатку розвивається мускариноподібний ефект, для якого характерні гіперсалівація та надмірна секреція потових залоз, бронхорея, посилення моторики шлунково-кишкового тракту, що 
супроводжуються блювотою та гастроентеритом, спастичними скороченнями стінки кишечнику. У бронхах нагромаджується надмірна кількість слизу та пінистої рідини. Також реєструють міоз (звуження зіниці ока). В окремих випадках розвивається гіперемія кон'юнктиви, посіпування повік. Можлива поява лярингоспазму, кашлю, утруднененого дихання та виділення пінистої рідини з носової та ротової порожнини. Якщо концентрація отрути $є$ недостатньою для настання загибелі тварини, протягом невеликого проміжку часу реєструються інші мускариноподібні симптоми: анорексія, тенезми, пронос, брадикардія, часті позиви до сечовипускання, м'язова слабкість, що зростає при фізичних навантаженнях. Також реєструються виражені симптоми ураження центральної нервової системи: збудження, тремор, паралічі, судоми, коматозний стан, зникнення рефлексів (Kagan, 1977; Dagaev et al., 1991; Kokshareva, 1999).

Нікотиноподібна дія розвивається 3 деяким запізненням та характеризується розвитком міофібриляції, регідності грудних м'язів, а надалі реєструється параліч дихальної мускулатури з розвитком різкої гіпоксемії. Унаслідок цього розвиваються зміни, характерні для асфіктичного синдрому: застійна гіперемія внутрішніх органів, чисельні крапкові або плямисті крововиливи на серозних та слизових оболонках. Важливим механізмом танатогенезу за отруєння фосфорорганічними пестицидами є поява кардіотоксичного ефекту з розвитком довготривалого декомпенсованого шоку. У таких випадках з'являється блокада нервового апарату гладких міоцитів судинної стінки та сповільнення провідності у міокарді. У термінальні періоди розвивається різке падіння рівня тиску крові та параліч центру дихання (Cherkesa, 1964; Kagan, 1977; Dagaev et al., 1991; Kokshareva, 1999).

Морфологічні зміни, що виникають в організмі за отруєння фосфорорганічними сполуками менш специфічні. Характер та інтенсивність змін коливаються в широких межах, причому досить часто не вдається прослідкувати взаємозв'язку між важкістю інтоксикації та вираженістю структурних змін. Зазвичай за хронічних інтоксикацій фосфорорганічними сполуками патологоанатомічні зміни більш яскраво виражені ніж у випадках, що закінчуються швидкою загибеллю тварин. Досить характерними змінами, що виникають за отруєння фосфорорганічними сполуками, $є$ спастичні скорочення гладких міоцитів, що призводить до міозу, спазмів кишечнику, бронхоспазму. За гострого отруєння фосфороргнанічними сполуками виявляють гостру застійну гіперемію внутрішніх органів, крапкові крововиливи, а у діафрагмі ділянки місцевої ішеміі. Верхні дихальні шляхи, а також трахея заповнені слизом або пінистою рідиною. У центральній нервовій системі реєструється гострий венозний застій, помірно виражений набряк оболонок та речовини головного мозку, дрібні периваскулярні крововиливи, що пов'язані з підвищенням проникності переважно артеріол. Дистрофічні зміни нервових клітин різних відділів головного мозку реєструються переважно за хронічних інтоксикацій. Альтеративні зміни гангліонарних клітин реєструються у спинному мозку та вегетативних гангліях. У тварин, які загину- ли у віддалені терміни після отруєння також реєструється розпад мієліну та осьових циліндрів нервових волокон, проліферація клітин глії (Kagan, 1977; Kagan et al., 1996; Dankovych and Tumanov, 2016; Noori et al., 2016).

У легенях, окрім гострої застійної гіперемії та помірно вираженого набряку, відзначають спастичні скорочення гладких міоцитів дрібних бронхів, звуження їх просвіту. Унаслідок цього в окремих ділянках виявляють дрібні фокуси ателектазу та емфіземи. В окремих випадках через декілька днів після отруєння може розвиватись дрібновогнищева пневмонія. У шлунку розвивається гострий катаральний гастрит фундального та антрального відділів, а у кишечнику гострий катаральний ентерит, що супроводжувався збільшенням кількості келихоподібних клітин, набряком та інтенсивною інфільтрацією слизової оболонки та підслизової основи лімфоїдними елементами. За ходом кишечнику реєструються спастичні скорочення м'язової оболонки кишок, які на гістологічних препаратах мають вигляд так званих «хвиль скорочення» Під епікардом, в міокарді та під ендокардом виявляють крапкові крововиливи. Також спостерігається розширення правого шлуночка та передсердя, дистрофічні зміни кардіоміоцитів (Kagan, 1977; Ahmedzhanov et al., 1978; Kagan et al., 1996; Dankovych and Tumanov, 2016).

Печінка застійно гіперемійована, під глісоновою капсулою виявляють дрібні крововиливи. Також реєструється дисоціація печінкових балок, жирова дистрофія гепатоцитів, множинні фокальні некрози. У підшлунковій залозі виявляють крововиливи під капсулу та у товщі органу. У селезінці реєструють спастичні скорочення гладких міоцитів трабекулярного аппарату. У нирках розвивається білкова дистрофія та некротичні зміни епітелію ниркових канальців (Kagan, 1977; Ahmedzhanov et al., 1978; Dankovych and Tumanov, 2016).

Більшість фосфорорганічних сполук володіє мутагенним, канцерогенним та тератогенним ефектами. Експериментальні дані щодо мутагенної та канцерогенної дії діазинону є неоднозначними. В хронічних експериментах на щурах та мишах виявлено збільшення частоти виникнення лімфом, лейкемій та гепатоцелюлярних карцином за впливу діазинону. Мутагенність діазинону вивчали у чисельних бактеріальних тестах та на клітинах ссавців в умовах in vitro в тестах на генні мутації, хромосомні аберації, а також in vivo у мікроядерному тесті. Встановлено збільшення частоти хромосомних аберацій за впливу діазинону. Проте такі зміни деякі дослідники пов'язують 3 цитотоксичною дією діазинону. Також наявні дані щодо індукції діазиноном сестринських хроматичних обмінів у тестах in vitro. Окрім цього, генотоксичний ефект діазинону виявлено у клітинах слизової оболонки носової порожнини людей, отриманих шляхом біопсії за дії не цитотоксичних концентрацій діазинону. У зв'язку з цим не слід виключати можливості генотоксичного механізму онкогенної дії діазинону (Matsuoka et al., 1976; Hatjian et al., 2000; Nedopytanska, 2010). 
Сьогодні значна увага приділяється дослідженню імунної системи як мішені токсичної дії ксенобіотиків. У численних експериментах на тваринах встановлено, що більшість фосфорорганічних пестицидів, у тому числі діазинон, здатні пригнічувати неспецифічну реактивність організму, викликати імунодефіцит, знижувати антитілогенез, порушувати формування специфічної імунної відповіді, що призводить до зростання ймовірність виникнення інфекційних захворювань. Діазинон належить до препаратів, що пригнічує неспецифічну реактивність та знижує здатність Тлімфобластів до проліферації. Досить актуальним є вивчення розвитку автоімунних механізмів ураження за впливу фосфорорганічних сполук (Kagan, 1977; Newcombe, 1992; Zhmin'ko, 1998; Galloway and Handy, 2013).

Забруднення навколишнього середовища фосфорорганічними пестицидами на рівні наднизьких доз може спричинити ураження ендокринних органів та чинити гормоноподібну дію. Зокрема з гормоноподібною дією пестицидів пов'язують порушення статевого розвитку в рептилій та птахів, фемінізацію у самців риб, погіршення якісних та кількісних показників сперми, зростання частоти виникнення злоякісних новоутворень органів статевої системи самців і самок (Crain et al., 1997; Cox, 2000; Prodanchuk et al., 2005; Nikitin, 2006).

Варто зазначити, що на сьогодні наявний широкий спектр недостатньо вивчених аспектів впливу діазинону, а також інших фосфорорганічних пестицидів на організм тварин та людини. Зокрема потребують фундаментального дослідження механізми токсичної та селективної дії фосфорорганічних пестицидів. Недостатньо вивченими $є$ структурні зміни, що розвиваються в центральній та периферичній нервовій системі, у внутрішніх органах тварин за впливу різних доз діазинону, а також механізм їхнього розвитку та значення для організму. Остаточно не з'ясованими є біологічні закономірності впливу діазинону на організм холоднокровних та теплокровних тварин. Неоднозначними, а іноді суперечливими, є дані щодо мутагенного та канцерогенного впливу діазинону. Потребує вивчення цілий ряд аспектів щодо віддаленої нейротоксичної дії, а також ендокринних порушень, що виникають за впливу фосфорорганічних пестицидів. Досить актуальним є питання судововетеринарної та судово-медичної діагностики свідомих несанкціонованих або випадкових отруєнь птахів (останні є дуже чутливими до дії зазначеного фосфорорганічного пестициду), а також інших видів тварин та людини (Dagaev et al., 1991; Dankovych and Tumanov, 2016).

Зважаючи на широке та різнопланове використання діазинону, вивчення його впливу на організм різних видів тварин $є$ актуальною проблемою ветеринарної та гуманної медицини і потребує поглибленого та всебічного дослідження.

\section{Бібліографічні посилання}

Aleksanrova, L.G., Goncharenko, N.G. (1983). Raspredelenie i vyvedenie diazinona iz organizma teplokrovnyh zhivotnyh pri razlichnyh putjah postuplenija. Gigiena i sanitarija. 5, 68-70 (in Russian).

Dagaev, V.N., Iskanderov, A.I., Samibaev, K.M. (1991). Kliniko-morfologicheskaja toksikodinamika otravlenij fosfororganicheskimi insekticidami. - Sudebnomedicinskaja jekspertiza. 2, 34-37 (in Russian).

Dankovych, R.S., Tumanov, V.V. (2016). Patomorfolohichni zminy za spontannoho otruiennia holubiv diazynonom. - Naukovyi visnyk Lvivskoho natsionalnoho universytetu veterynarnoi medytsyny ta biotekhnolohii im. S.Z. Hzhytskoho. 18(3), 74-77 (in Ukrainian).

Zhmin'ko, P.G. (1998). Narushenie funkcii sistemy immuniteta pod vozdejstviem pesticidov i nekotorye zadachi immunotoksikologii na sovremennom jetape (obzor). Sovremennye problemy toksikologii. 2, 3337 (in Russian).

Kagan, Ju.S., Antonovich, E.A., Velikij, V.I. (1996). Klasifikacija pesticidov po stepeni opasnosti. Zhurn. AMN Ukrainy. 2(3), 465-476 (in Russian).

Kagan, Ju.S. (1977). Toksikologija fosfororganicheskih pesticidov. M., Medicina (in Russian).

Kodonidi, I.P. (2011). Molekuljarnoe konstruirovanie i celenapravlennyj sintez N-proizvodnyh 1,3-diazinona4. Avtoreferat dissertacii na soiskanie uchenoj stepeni doktora farmacevticheskih nauk. Pjatigorsk (in Russian).

Kokshareva, N.V., Kagan, Ju.S., Tkachenko, I.I. (1990). Problema otdalennogo nejrotoksicheskogo dejstvija fosfororganicheskih pesticidov (Obzor). Gigiena i sanitarija. 2, 62-67 (in Russian).

Kokshareva, N.V. (1999). Razvitie issledovanij po nejrotoksikologii (Obzor). Sovremennye problemy toksikologii. 4, 13-17 (in Russian).

Nedopytanska, M.N. (2010). Diazynon. Problema kantserohennoi nebezpeky ta pereotsinka toksykolohichnykh vlastyvostei. Sovremennye problemy toksikologii. 4, 29-38 (in Ukrainian).

Nikitin, A.I. (2006). Gormonopodobnye ksenobiotiki i ih rol' $\mathrm{v}$ patologii reproduktivnoj funkcii cheloveka. Jekologija cheloveka. 1, 9-16 (in Russian).

Ahmedzhanov, K.A., Saidkarimov, S.K., Tadzhiev, B.A. (1978). Patomorfologicheskie izmenenija kishechnika i pecheni krys pri vozdejstvii bazudina. Gigienicheskie i biologicheskie aspekty primenenija pesticidov v uslovijah Srednej Azii i Kazahstana. Dushanbe, 210-212 (in Russian).

Perelik pestytsydiv i ahrokhimikativ, dozvolenykh do vykorystannia v Ukraini. Ofitsiine vydannia. K.: Yunivest Media (2010) (in Ukrainian).

Prodanchuk, M.H., Zhminko, P.H., Nedopytanska, N.M. (2005). Osnovni problemy toksykolohii pestytsydiv i ahrokhimikativ ta yikh rehlamentatsii $\mathrm{v}$ obiektakh navkolyshnoho seredovyshcha (ohliad literatury ta vlasnykh doslidzhen). Zhurn. AMN Ukrainy. 4, 753774 (in Ukrainian).

Cherkesa, A.I. (1964). Rukovodstvo po toksikologi otravljajushhih veshhestv. Pod red. K., Zdorov'ja (in Russian).

Crain, D.A., Guillete, L.J., Rooney, A.A. (1997). Alterations in steroidogenesis in alligators (Alligator mis- 
sisspiensis) exposed naturally and experimentally to environmental contaminats. Environmental Health Perspectives. 105(10), 528-533.

Botha, C., Coetser, H., Labuschagne, L. (2015). Confirmed organophosphorus and carbamate pesticide poisonings in South African wildlife (2009-2014) Journal of the South African Veterinary Association. 86(1), 1329-1335.

Matsuoka, A., Hayashi, M., Ishidate, M.Jr. (1979). Chromosomal aberration tests on 29 chemicls with S9 mix in vitro. Mutat Res. 66(3), 277-290.

Hatjian, B.A., Mutch, E., Williams, F.M. (2000). Cytogenetic response without changes in peripheral cholinesterase enzymes following exposure to a sheep dip containing diazinon in vitro. Mut. Res. 472, 85-92.

Debski, B., Kania, B., Kuryl, T. (2007). Transformations of diazinon, an organophophoshate compound in the environment and poisoning by this compound. Ekológia (Bratislava). 26(1), 68-82.

Diazinon. NPIC technical fact sheet (http://npic.orst.edu/factsheets/inearts.pdf, http://npic. orst. Edu/ factsheets/signalwords.pdf)

EFSA Scientific Report (2006). 85, 1-73, Conclusion regarding the peer review of the pesticide risk assessment of diazinon. http: // www.efsa.europa.eu/efsa.europa.eu / EFSA PRAPER Conclusion / praper-concl-sr-74-diazinon-rev2publicen, 0. pdf

Environmental Protection Agency (2003). Pesticides: topical and chemical fact sheets. Washington, DC:
U.S. Enviromental Protection Agency. http: // www.epa.gov/REDs/factsheets/diazinon_red.pdf.

Galloway, T., Handy, R. (2013). Immunotoxity of organophosphorous pesticides. Ecotoxicology. 12, 345-363.

Newcombe, D.S. (1992). Immune surveillance, organophosphorus exposure, and lymphomagenesis. Lancet, 339, 539-541.

Noori, A., Amjad L., Yazdani F. (2016). The Antioxidant effects of Artemisia deserti ethanolic extract and diazinon on mail rat kidney. Zahedan journal of research in medical sciences. $15,1-6$.

Cox, C. (2000). Diazinon: toxicology. Journal of pesticide reform. 20(2), 15-21.

Reregistration Eligibility Decision (RED) for Diazinon (2006); EPA 738-R-04-006; U.S. Environmental Protection Agency, Office of Prevention, Pesticides and Toxic Substances, Office of Pesticides Programs, U.S. Government Printing Office: Washington DC http://www.epa.gov/ oppssrrdl/reregistration/REDs/diazinon_red.

Tomlin, C.D. (2006). The pesticide manual: a world compendium. British Crop Protection Council (BCPC). Hampshire.

WHO (1998). Environmental Health Criteria 198. Diazinon. Internettional Programme on Chemical Safety, World Health Organization: Geneva, Switzerland.

Стаття надійшла до редакиії 1.03.2017 